\title{
Nutritional Requirements of Zymomonas mobilis CCT 4494 for Levan Production
}

\author{
Fernanda Maria Pagane Guereschi Ernandes" and Crispin Humberto Garcia-Cruz \\ Departamento de Engenharia e Tecnologia de Alimentos, Instituto de Biociências, Letras e Ciências; Universidade \\ Estadual Paulista; Rua Cristóvão Colombo, 2265; 15054-000; São José do Rio Preto - SP - Brasil
}

\begin{abstract}
The aim of this work was to study the nutritional requirements of Zymomonas mobilis CCT 4494 for levan production in three chemically defined media. During the optimization of the fermentative process for the production of the exopolysaccharide, different concentrations of glucose, fructose and sucrose as carbon source and yeast extract as vitamin source were tested. Variations of incubation temperature and initial pH of the medium were observed. The results showed that medium containing $20.0 \%$ sucrose and $0.5 \%$ yeast extract, with initial pH of 7.0 , incubated at $30^{\circ} \mathrm{C}$ gave a $43.0 \%$ yield of the biopolymer.
\end{abstract}

Key words: Zymomonas mobilis, levan, exopolysaccharide, production

\section{INTRODUCTION}

The modern food industry is becoming more and more dependent on the production of highly processed foods, instead of just preserving raw material obtained in the field. A lot of this development, however, has been a result of the creativity or empirical manipulation, many times by trials and errors procedures, of ingredients with little scientific information. One such class of polysaccharides is hydrocolloids or gums and their most important characteristic is the ability to define or modify the structure of foods (Sutherland, 2001). Polysaccharides of microbial sources, called biopolymers, exhibit some advantages when compared to other gums, such as the production not dependent on climate conditions, possibility of using regional resources, faster finished product and need of less physical space for manufacturing installations. In addition, they exhibit more uniform physical and chemical characteristics due to microorganism specificity and possibility of a strict fermentation process control of parameters such as $\mathrm{pH}$, temperature, aeration rate, agitation speed, time and culture medium composition (Borsari et al., 2006).

Exopolysaccharide such as xantan, have been used for years by the food industry due to its thickening and stabilizing properties. Dextran is used in the pharmaceutical industry as glucose source. In spite of the fact that all of these exopolysaccharides exhibit attractive functional properties, the search for new bacterial polysaccharides continues to take place. Among these, levan offers potential advantages for applications in the health and food industries (Pace and Righelato, 1980). Levan is a natural polymer of frutose with $\beta$ 2-6 linkage. Many microorganism such as Bacillus subtilis, Aerobacter levanicum, Erwinia herbicola, Streptococcus salivarius and Zymomonas mobilis

*Author for correspondence: fernandaer@ig.com.br 
produce levan of high molecular weight when grown in sucrose medium. Levan has potential commercial importance as fructose sweetner, thickening agent in food industry, antitumoral agent and pharmaceutical application (Sangiliyandi et al., 2000).

The application potential of levan in the food and pharmaceutical sectors is stimulating an intense and constant search aiming for a better understanding of the metabolic pathways for their synthesis and physiological function. There is also an interest in the biology of the producing microorganisms aiming a regulation of their formation and optimization of the production process (Oliveira et al., 2007; Ernandes and Garcia-Cruz, 2009).

This work had the aim to study the nutritional requirements of Z. mobilis CCT 4494 for levan production in three chemically defined medium were studied.

\section{MATERIALS AND METHODS}

\section{Microorganism}

Z. mobilis CCT 4494 was obtained from the Fundação Tropical de Pesquisas e Tecnologia André Tosello (Campinas, Brazil).

\section{Maintenance medium}

The bacterial strain was cultivated and maintained in basal medium containing (g. $\mathrm{L}^{-1}$ ) clarified sugar cane broth 100.0, distilled water $30.0, \mathrm{CaCO}_{3} 0.4$, yeast extract 0.4 , nutrient agar 1.5 and $\mathrm{pH}$ adjusted to 7.0 (Swings et al., 1977). The strain was subcultured every two months. The culture was incubated at $30^{\circ} \mathrm{C}$ for $48 \mathrm{~h}$ and stored at $4^{\circ} \mathrm{C}$.

\section{Pre-inoculum preparation}

Z. mobilis CCT 4494 was activated in slants containing the maintenance medium by incubating at $30^{\circ} \mathrm{C}$ for $24 \mathrm{~h}$. After the incubation time, bacterial cells were suspended by adding $5.0 \mathrm{~mL}$ of sterilized distilled water and transferred to 250 $\mathrm{mL}$ Erlenmeyer flasks containing $50 \mathrm{~mL}$ of the production medium with initial $\mathrm{pH}$ of 7.0. The flasks were placed on orbital shaker (model Marconi MA 830) under controlled temperature $\left(30^{\circ} \mathrm{C}\right), 200 \mathrm{rpm}$, for $24 \mathrm{~h}$ period. The prefermentation medium used was made up medium 1,2 or 3 with the addition of 20.0 g.L $\mathrm{L}^{-1}$ of sucrose.

\section{Fermentation}

The Erlenmeyer flasks containing $50 \mathrm{~mL}$ of the production medium were inoculated with the bacterium suspension from the pre-fermentation and incubated in orbital shaker at $30^{\circ} \mathrm{C}, 200 \mathrm{rpm}$ for $72 \mathrm{~h}$. Initial $\mathrm{pH}$ and temperature of the medium were established for each experiment. The bacterium suspension volume added to each flask was standardized in a spectrophotometer for OD as 0.3 at $650 \mathrm{~nm}$ (Cintra 5 UV-VIS "Double Beam") and calculated the volume inoculum as described by Faria (2002). The inoculum was equivalent to $0.28 \mathrm{mg}$ dry cell weight $150 \mathrm{~mL}$ of fermentation medium.

\section{Production medium}

Three media, designated as production medium 1, 2 and 3, with the addition of different concentrations of carbon source (glucose, fructose and sucrose) and yeast extract for levan production. Medium 1, described by Euzenat et al. (1996) with some modifications, contained ( g.L $\mathrm{L}^{-1}$ ) yeast extract $2.0 ; \mathrm{K}_{2} \mathrm{HPO}_{4} 1.09 ; \mathrm{KH}_{2} \mathrm{PO}_{4} 2.09$; $\left(\mathrm{NH}_{4}\right)_{2} \mathrm{SO}_{4} 3.3 ; \mathrm{MgSO}_{4} .7 \mathrm{H}_{2} \mathrm{O}$ 0.06; $\mathrm{MnSO}_{4} .7$ $\mathrm{H}_{2} \mathrm{O} 0.0172$ and Ferric citrate (0.022). Medium 2, described by Garcia-Cruz (1997) contained ( g.L $\mathrm{L}^{-1}$ ) yeast extract 2.0; $\mathrm{KH}_{2} \mathrm{PO}_{4} \quad 5.0 ; \quad \mathrm{K}_{2} \mathrm{HPO}_{4} \quad 1.0$; $\left(\mathrm{NH}_{4}\right)_{2} \mathrm{SO}_{4} \quad 2.0 ; \mathrm{NaCl} \quad 0.5 ; \mathrm{CaCl}_{2} .6 \quad \mathrm{H}_{2} \mathrm{O} \quad 0.1$; $\mathrm{MgSO}_{4} .7 \mathrm{H}_{2} \mathrm{O} 0.1$ and $\mathrm{MnSO}_{4} .7 \mathrm{H}_{2} \mathrm{O} 0.01$ Medium 3, described by Rodriguez and Callieri (1986) contained ( g. $\mathrm{L}^{-1}$ ) yeast extract $5.0 ; \mathrm{KH}_{2} \mathrm{PO}_{4}$ 1.0; $\left(\mathrm{NH}_{4}\right)_{2} \mathrm{SO}_{4} 1.0$ and $\mathrm{MgSO}_{4} .7 \mathrm{H}_{2} 0$ 1.0.

\section{Kinetic parameters for levan production}

Effect of different carbon sources

Different concentrations of fructose, glucose and sucrose $(1,2,3,4$ and $5 \%$ ) were tested. Fermentations were carried out in triplicate by incubating on at $30^{\circ} \mathrm{C}$ and $200 \mathrm{rpm}$ for $72 \mathrm{~h}$. Initial $\mathrm{pH}$ of the media was adjusted to 7.0 by the addition of $10 \mathrm{~N} \mathrm{NaOH}$ or $\mathrm{HCl}$.

\section{Effect of high concentrations of sucrose}

This experiment evaluated the influence of high concentrations of sucrose added in three media for biopolymer production. The fermentation conditions performed with the bacterium were similar to those of the previous experiment. The concentrations of sucrose were 10,15 and $20 \%$

Effect of incubation temperature and initial $p H$ The effects of these parameters on levan formation 
were studied in the medium 3 with $20 \%$ sucrose. Initial $\mathrm{pH}$ values were adjusted to $6.0 ; 7.0$ and 8.0 with $10 \mathrm{~N} \mathrm{NaOH}( \pm 0.5)$. Fermentations were carried out at 25,30 and $35^{\circ} \mathrm{C}$ at $200 \mathrm{rpm}$, for $72 \mathrm{~h}$.

\section{Effect of yeast extract}

The effect of different yeast extract concentrations (1.0 to 10.0, g. $\mathrm{L}^{-1}$ ) in medium 3 containing $20 \%$ sucrose was studied. Fermentations were carried at $30^{\circ} \mathrm{C}$ and $200 \mathrm{rpm}$, for $72 \mathrm{~h}$; control experiment did not contain yeast extract in the medium.

\section{Analytical Methods}

The final $\mathrm{pH}$ was determined directly in the fermented broth obtained after the end of fermentation by potentiometry $(\mathrm{pH}$ meter model Digmed DM20). To determine the levan concentration, the samples from the fermented broth were centrifuged (Jouan model GR2022) at $3123 \mathrm{~g}$ and $4^{\circ} \mathrm{C}$ for $15 \mathrm{~min}$ The supernatant was mixed with three volumes of cooled ethanol (Jeanes et al., 1976) and the precipitate was dried in a vacuum oven at $45^{\circ} \mathrm{C}$ (Fanem, 0002CD) for approximately $24 \mathrm{~h}$ (Mello et al., 2007). The levan yield was calculated by the ratio between the weight of the produced polysaccharide and weight of the carbon source intake. The production of the polysaccharide was quantified by estimating fructose according to Somogyi (1952) and Nelson (1944) method. For this, levan was separeted by ethanol precipitation, hydrolyzed in $0.5 \% \mathrm{HCl}$ at $100^{\circ} \mathrm{C}$ for 60 minutes (Viikari, 1986) and estimated as fructose. The ash content of the crude polysaccharide was determined by method as described in Normas Técnicas do Instituto Adolfo Lutz (1985). Cellular mass (CM) was determined through the by dry cellular weight in vacuum oven, at $45^{\circ} \mathrm{C}$ (Fanem, 0002CD). Total reducing sugar (TRS) and reducing sugar (RS) were measured by the Dinitrosalicylic Acid Method (DNS) as described by Miller (1959). Total reducing sugar was determined after acid hydrolysis with $\mathrm{HCl}(1 \mathrm{~N})$ according to Amorin (1982). The residual sucrose was obtained by difference between ART and AR.

\section{RESULTS AND DISCUSSION}

The effect of cultivation conditions for the production of extracellular polysaccharides by microbial species has been studied for cultures undergoing growth as well as for cells in suspensions. Limitations of nitrogen, phosphate or sulfur sources in the presence of carbohydrates in excess have also been studied. It has been noted that they could lead to an increase of polysaccharide synthesis although the quantity is also affected by oxygen content, $\mathrm{pH}$ and temperature. Each strain presents different responses towards the environmental changes and towards the use of carbon source. Ideal conditions for microbial development and for polysaccharide production in batch cultures are also affected by the proportion between the air and medium volume, use of agitation or steady state, inoculum size and also the nutrients that make up the culture medium (Ernandes and Garcia-Cruz, 2005; 2009). Thus, in this study, some chemical compounds present in different media suggested as essential part of the nutritional requirements of $Z$. mobilis were tested.

\section{Effect of different carbon sources}

According to Doelle et al. (1989) and Park and Baratti (1993), many microorganisms need high sugar concentrations for levan production. To verify this hypothesis and to determine the ideal substrate concentration for the biopolymer production, different concentrations of fructose, glucose and sucrose were tested for Z. mobilis CCT 4494. Results are presented in Table 1. In the different production media the culture displayed different behaviors, and its growth was directly affected by carbon source and by its concentration. The culture grew in $\mathrm{pH}$ range from 3.6 to 5.9 in the media tested.

Z. mobilis didn't produce levan in media 1 and 2 . The biopolymer was synthesized only in medium 3 and the $\mathrm{pH}$ values that resulted in better yields were between 4.0 and 5.5 (Table 1). Similar values were reported by Lyness and Doelle (1983), suporting that $\mathrm{pH}$ was an important factor for the polysaccharide production, since high or very low values repressed levansucrase, the enzyme responsible for the biopolymer formation. 
Table 1- Levan production by Z. mobilis CCT 4494 in media 1, 2 and 3 containing of different fructose, glucose and sucrose concentration at $30^{\circ} \mathrm{C}$ and $200 \mathrm{rpm}$ for $72 \mathrm{~h}$.

\begin{tabular}{|c|c|c|c|c|c|c|}
\hline \multirow{2}{*}{\multicolumn{2}{|c|}{ Carbon source }} & \multicolumn{5}{|c|}{ Concentrations $\left(\right.$ g. $\left.\mathbf{L}^{-1}\right)$} \\
\hline & & \multirow[t]{2}{*}{10} & \multirow{2}{*}{30} & 40 & $\mathbf{5 0}$ & \\
\hline \multicolumn{5}{|c|}{ Medium 1} & & \\
\hline & final $\mathrm{pH}$ & $4.5( \pm 0.1)$ & $4.8( \pm 0.0)$ & $4.8( \pm 0.1)$ & $4.7( \pm 0.1)$ & $4.8( \pm 0.1)$ \\
\hline \multirow[t]{2}{*}{ Fructose } & $\mathrm{CM}\left(\mathrm{g} . \mathrm{L}^{-1}\right)$ & $.1( \pm 0.1)$ & $1.3( \pm 0.1)$ & $1.3( \pm 0.1)$ & $1.6( \pm 0.1)$ & $1.7( \pm 0.2)$ \\
\hline & final $\mathrm{pH}$ & $4.6( \pm 0.1)$ & $4.6( \pm 0.1)$ & $4.6( \pm 0.0)$ & $4.6( \pm 0.1)$ & $4.6( \pm 0.1)$ \\
\hline \multirow[t]{2}{*}{ Glucose } & $\mathrm{CM}\left(\mathrm{g} \cdot \mathrm{L}^{-1}\right)$ & $1.9( \pm 0.1)$ & $2.0( \pm 0.0)$ & $2.2( \pm 0.2)$ & $2.4( \pm 0.0)$ & $2.5( \pm 0.0)$ \\
\hline & final $\mathrm{pH}$ & $4.4( \pm 0.0)$ & $4.4( \pm 0.0)$ & $4.4( \pm 0.0)$ & $4.4( \pm 0.0)$ & $4.4( \pm 0.0)$ \\
\hline \multirow[t]{3}{*}{ Sucrose } & $\mathrm{CM}\left(\mathrm{g} \cdot \mathrm{L}^{-1}\right)$ & $1.1( \pm 0.1)$ & $1.2( \pm 0.2)$ & $1.3( \pm 0.0)$ & $1.3( \pm 0.0)$ & $1.4( \pm 0.0)$ \\
\hline & & & Me & edium 2 & & \\
\hline & final $\mathrm{pH}$ & $3.9( \pm 0.1)$ & $3.8( \pm 0.1)$ & $3.8( \pm 0.1)$ & $3.7( \pm 0.0)$ & $3.7( \pm 0.0)$ \\
\hline \multirow[t]{2}{*}{ Fructose } & $\mathrm{CM}\left(\mathrm{g} . \mathrm{L}^{-1}\right)$ & $1.3( \pm 0.1)$ & $1.6( \pm 0.1)$ & $1.7( \pm 0.0)$ & $1.8( \pm 0.0)$ & $2.0( \pm 0.1)$ \\
\hline & final $\mathrm{pH}$ & $3.9( \pm 0.1)$ & $3.7( \pm 0.0)$ & $3.6( \pm 0.0)$ & $3.6( \pm 0.0)$ & $3.4( \pm 0.0)$ \\
\hline \multirow[t]{2}{*}{ Glucose } & $\mathrm{CM}\left(\mathrm{g} \cdot \mathrm{L}^{-1}\right)$ & $1.9( \pm 0.1)$ & $1.9( \pm 0.0)$ & $2.1( \pm 0.1)$ & $2.2( \pm 0.1)$ & $2.5( \pm 0.0)$ \\
\hline & final $\mathrm{pH}$ & $3.8( \pm 0.1)$ & $3.7( \pm 0.0)$ & $3.7( \pm 0.0)$ & $3.6( \pm 0.1)$ & $3.6( \pm 0.0)$ \\
\hline \multirow[t]{3}{*}{ Sucrose } & $\mathrm{CM}\left(\mathrm{g} \cdot \mathrm{L}^{-1}\right)$ & $1.8( \pm 0.1)$ & $2.0( \pm 0.0)$ & $2.0( \pm 0.0)$ & $2.1( \pm 0.1)$ & $2.3( \pm 0.1)$ \\
\hline & & & & edium 3 & & \\
\hline & final $\mathrm{pH}$ & $4.5( \pm 0.2)$ & $4.6( \pm 0.1)$ & $4.5( \pm 0.0)$ & $4.7( \pm 0.1)$ & $4.7( \pm 0.2)$ \\
\hline \multirow[t]{2}{*}{ Fructose } & $\mathrm{CM}\left(\mathrm{g} \cdot \mathrm{L}^{-1}\right)$ & $1.7( \pm 0.2)$ & $2.0( \pm 0.0)$ & $2.1( \pm 0.0)$ & $2.4( \pm 0.0)$ & $2.6( \pm 0.1)$ \\
\hline & final $\mathrm{pH}$ & $5.9( \pm 0.2)$ & $5.6( \pm 0.2)$ & $5.4( \pm 0.1)$ & $5.2( \pm 0.2)$ & $5.1( \pm 0.0)$ \\
\hline \multirow[t]{2}{*}{ Glucose } & $\mathrm{CM}\left(\mathrm{g} . \mathrm{L}^{-1}\right)$ & $2.5( \pm 0.2)$ & $2.7( \pm 0.2)$ & $2.9( \pm 0.1)$ & $2.8( \pm 0.0)$ & $3.3( \pm 0.1)$ \\
\hline & final $\mathrm{pH}$ & $4.5( \pm 0.2)$ & $4.3( \pm 0.1)$ & $4.2( \pm 0.2)$ & $4.3( \pm 0.1)$ & $4.3( \pm 0.1)$ \\
\hline \multirow[t]{6}{*}{ Sucrose } & $\mathrm{CM}\left(\mathrm{g} . \mathrm{L}^{-1}\right)$ & $1.8( \pm 0.0)$ & $2.4( \pm 0.2)$ & $2.5( \pm 0.0)$ & $2.6( \pm 0.2)$ & $3.0( \pm 0.0)$ \\
\hline & $\operatorname{Levan}\left(\mathrm{g} . \mathrm{L}^{-1}\right)$ & - & - & - & $6.4( \pm 0.2)$ & $11.9( \pm 0.1)$ \\
\hline & Levan (\%) & - & - & - & $16.0( \pm 0.2)$ & $23.8( \pm 0.1)$ \\
\hline & TRS $\left(\right.$ g. $\left.\mathrm{L}^{-1}\right)$ & nd & nd & nd & $16.3( \pm 0.1)$ & $10.9( \pm 0.1)$ \\
\hline & Sc $\left(\mathrm{g} . \mathrm{L}^{-1}\right)$ & nd & nd & nd & $23.7( \pm 0.1)$ & $39.1( \pm 0.1)$ \\
\hline & $\operatorname{Ash}(\%)$ & nd & nd & nd & $4.6( \pm 0.2$ & 2) $3.4( \pm 0.2)$ \\
\hline
\end{tabular}

Initial pH: 7.0. CM: cellular mass. - : no levan production. TRS: Total Reducing Sugar. Sc: substrate consumed. nd: not determined; $( \pm)$ : average of three determinations indicating the range upper and lower values obtained for each experiment. $Z$. mobiis didn't produce levan in Media 1 and 2 containing glucose, fructose and sucrose. Z. mobiis didn't produce levan in Medium 3 containing glucose and fructose.

Generally, as carbon source increased, there was an increase of cellular mass. This could be seen in Table 1, where fructose and glucose only stimulated bacterial growth. This Table showed that sucrose, besides stimulating the cellular growth, also promoted levan synthesis, which indicated selectiveness of the sugars used as substrate. Similar results, regarding the restricted use of sugars as substrate for levan production, were also found by other researchers. Dadds and Martin (1973), for example, reported that $Z$. mobilis needed a fermentative sugar in its culture medium to grow, such as glucose or fructose or even, for some strains, sucrose. However, Ribbons et al. (1962) stated that this microorganism produced levan only from sucrose and not from glucose, fructose or a mixture of both. In the present study, although glucose medium did not result in levan production the cellular growth rate of the culture was higher than in media containing sucrose and fructose. The highest cellular mass was $3.3 \mathrm{~g} . \mathrm{L}^{-1}$ in medium 3 , which contained initial glucose concentration of 50.0 g. $\mathrm{L}^{-1}$. Dawes et al. (1966) obtained the same results and observed that 
medium containing sucrose gave the lowest growth and the highest levan production. Cote and Ahlgren (1993) studied the growth of Erwinia herbicola and the production of levansucrase in different fermentation media. They compared the cellular densities and observed a lower cell concentration when fructose was used as the carbon source. In the present study, fructose resulted the lowest cellular growth in media 2 and 3 , with exception of medium 1 where fructose was better than sucrose. The biopolymer production in medium 3 was 16.0 and $23.8 \%$ with 4.0 and $5.0 \%$ of sucrose, respectively. In media 1 and 2 also containing sucrose, the bacteria did not produce levan. Regarding Total Reducing Sugar (TRS), it was noted that sucrose intake by the bacteria was proportional to levan synthesis, in the conditions provided to the bacteria during the fermentative process, reaching intake values of 23.7 g.L $\mathrm{L}^{-1}$ $(59.2 \%)$ and 39.1 g. $\mathrm{L}^{-1}(78.2 \%)$ with 4 and $5 \%$ sucrose, respectively in medium 3 (Table 1). These results showed that during fermentation, the carbon source was converted by the microbial cell into biopolymer under defined parameters $(\mathrm{pH}$, temperature, incubation time, etc.), and that the limiting concentrations of some nutrients and the higher concentration of carbohydrate favored the polysaccharide production as observed by Sutherland (2001).

\section{Effect of high concentrations of sucrose}

The results of the effect of sucrose addition regarding final $\mathrm{pH}$ value, cell mass concentration, levan concentration, yield total, reducing sugar and consumed sucrose after $72 \mathrm{~h}$ of fermentation and ash content of the polysaccharide produced are presented in Table 2. Evidently the carbon source used was an excellent substrate for the growth of Z. mobilis and also, as its concentration increased, cell mass and levan yield also increased. The results indicated that the increase in sucrose concentration did not only favor the cell growth but also levan formation.

Table 2 - Levan production by Z. mobilis CCT 4494 in media 1,2 and 3 containing of different sucrose concentrations at $30^{\circ} \mathrm{C}$ and $200 \mathrm{rpm}$ for $72 \mathrm{~h}$

\begin{tabular}{|c|c|c|c|c|}
\hline \multicolumn{5}{|c|}{ Sucrose $\left(\right.$ g. $\left.\mathbf{L}^{-1}\right)$} \\
\hline Medium & & 100 & 150 & 200 \\
\hline \multirow{7}{*}{1} & final $\mathrm{pH}$ & $4.1( \pm 0.1)$ & $4.1( \pm 0.0)$ & $4.0( \pm 0.0)$ \\
\hline & $\mathrm{CM}\left(\mathrm{g} \cdot \mathrm{L}^{-1}\right)$ & $3.0( \pm 0.0)$ & $3.5( \pm 0.0)$ & $4.2( \pm 0.2)$ \\
\hline & $\operatorname{Levan}\left(\mathrm{g} \cdot \mathrm{L}^{-1}\right)$ & $22.6( \pm 0.2)$ & $49.8( \pm 0.0)$ & $31.8( \pm 0.0)$ \\
\hline & Levan $(\%)$ & $22.6( \pm 0.2)$ & $33.2( \pm 0.0)$ & $15.9( \pm 0.0)$ \\
\hline & TRS $\left(\mathrm{g} \cdot \mathrm{L}^{-1}\right)$ & $15.6( \pm 0.1)$ & $20.2( \pm 0.2)$ & $37.4( \pm 0.2)$ \\
\hline & Sc $\left(\mathrm{g} . \mathrm{L}^{-1}\right)$ & $84.4( \pm 0.1)$ & $129.8( \pm 0.2)$ & $162.6( \pm 0.2)$ \\
\hline & $\operatorname{Ash}(\%)$ & $5.5( \pm 0.0)$ & $2.2( \pm 0.2)$ & $1.9( \pm 0.1)$ \\
\hline \multirow{7}{*}{2} & final $\mathrm{pH}$ & $4.2( \pm 0.0)$ & $4.3( \pm 0.1)$ & $4.2( \pm 0.0)$ \\
\hline & $\mathrm{CM}\left(\mathrm{g} \cdot \mathrm{L}^{-1}\right)$ & $4.4( \pm 0.1)$ & $4.6( \pm 0.1)$ & $5.7( \pm 0.2)$ \\
\hline & Levan $\left(\right.$ g. $\left.\mathrm{L}^{-1}\right)$ & $6.4( \pm 0.0)$ & $41.1( \pm 0.0)$ & $59.7( \pm 0.1)$ \\
\hline & Levan $(\%)$ & $6.4( \pm 0.0)$ & $27.4( \pm 0.0)$ & $29.8( \pm 0.1)$ \\
\hline & $\operatorname{TRS}\left(\mathrm{g} \cdot \mathrm{L}^{-1}\right)$ & $31.0( \pm 0.3)$ & $46.2( \pm 0.2)$ & $39.6( \pm 0.1)$ \\
\hline & $\operatorname{Sc}\left(\mathrm{g} . \mathrm{L}^{-1}\right)$ & $69.0( \pm 0.3)$ & $103.8( \pm 0.2)$ & $60,4( \pm 0.1)$ \\
\hline & $\operatorname{Ash}(\%)$ & $5.9( \pm 0.3)$ & $4.9( \pm 0.0)$ & $4.5( \pm 0.0)$ \\
\hline \multirow{7}{*}{3} & final $\mathrm{pH}$ & $4.4( \pm 0.1)$ & $4.5( \pm 0.0)$ & $4.4( \pm 0.0)$ \\
\hline & $\mathrm{CM}\left(\mathrm{g} \cdot \mathrm{L}^{-1}\right)$ & $3.3( \pm 0.1)$ & $4.2( \pm 0.0)$ & $4.6( \pm 0.2)$ \\
\hline & $\operatorname{Levan}\left(\mathrm{g} \cdot \mathrm{L}^{-1}\right)$ & $26.1( \pm 0.2)$ & $42.4( \pm 0.3)$ & $85.4( \pm 0.2)$ \\
\hline & Levan $(\%)$ & $26.1( \pm 0.2)$ & $28.3( \pm 0.3)$ & $42.7( \pm 0.2)$ \\
\hline & $\operatorname{TRS}\left(\mathrm{g} . \mathrm{L}^{-1}\right)$ & $39.3( \pm 0.2)$ & $43.3( \pm 0.3)$ & $15.3( \pm 0.3)$ \\
\hline & Sc $\left(\mathrm{g} \cdot \mathrm{L}^{-1}\right)$ & $60.7( \pm 0.2)$ & $106.7( \pm 0.3)$ & $184.7( \pm 0.3)$ \\
\hline & $\operatorname{Ash}(\%)$ & $1.5( \pm 0.0)$ & $0.9( \pm 0.0)$ & $0.7( \pm 0.1)$ \\
\hline
\end{tabular}

Initial pH: 7.0. CM: cellular mass. TRS: Total Reducing Sugar. Sc: substrate consumed. ( \pm ): average of three determinations indicating the range upper and lower values obtained for each experiment. 
Figure 1 showed that there was no difference in the biopolymer synthesis when sucrose concentrations were between $100\left(26.1\right.$ g. $\left.\mathrm{L}^{-1}\right)$ and 150 g.L. $\mathrm{L}^{-1}\left(28.3\right.$ g.L $\left.\mathrm{L}^{-1}\right)$ in medium 3 . However, in the same medium, levan formation exhibited an increase to $42.7 \%$ ( 85.4 g.L $\mathrm{L}^{-1}$ ) when initial sucrose concentration was 200 g. $\mathrm{L}^{-1}$, which could be considered as ideal for the exopolysaccharide synthesis. Similar results were observed by Euzenat et al. (1997), who reported f approximately $30.0 \%$ levan production by Bacillus subtilis CCT 0089 with same sucrose concentrations. The highest levan yield by $Z$ mobilis CCT 4494 in medium 2 was also with 200 g. $\mathrm{L}^{-1}$ sucrose concentration $\left[29.8 \%\left(59.7\right.\right.$ g. $\left.\left.\mathrm{L}^{-1}\right)\right]$. However, it was lower than the yield obtained in medium 3 (Fig. 1). Vinhas (1999) compared different $Z$. mobilis strains for levan production using 200 and 250 g.L $\mathrm{L}^{-1}$ sucrose at $25^{\circ} \mathrm{C}$ for $72 \mathrm{~h}$ and the results showed that the best producing strain was Z. mobilis ZAG-12, and that the best fermentation conditions were with initial sucrose concentration of 200 g. $\mathrm{L}^{-1}$ and without agitation.

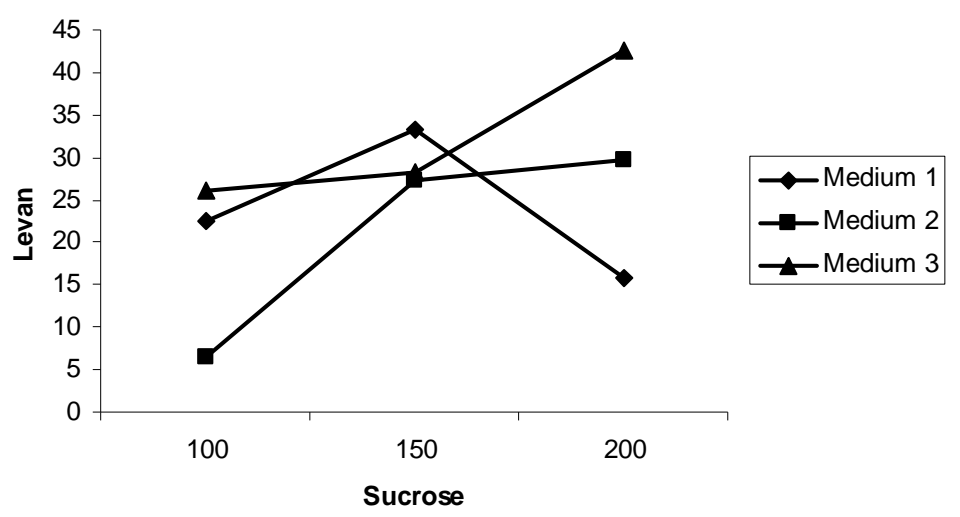

Figure 1 - Levan production by Z. mobilis CCT 4494 in media 1, 2 and 3 containing of different sucrose concentrations at $30^{\circ} \mathrm{C}$ and $200 \mathrm{rpm}$ for $72 \mathrm{~h}$.

Levan production by Z. mobilis CCT 4494 in media 1,2 and 3 containing different concentrations of sucrose at $30^{\circ} \mathrm{C}$ and $200 \mathrm{rpm}$ for $72 \mathrm{~h}$

As shown in Figure 1 in medium 1, the ideal sucrose concentration was 150 g.L. ${ }^{-1}$, with a $33.2 \%$ (49.8 g. $\mathrm{L}^{-1}$ ) yield. Some other studies have also reported 150 g. $\mathrm{L}^{-1}$ of initial sucrose as optimum for levan formation by Z. mobilis strains. Viikari and Gisler (1986) varied initial sucrose concentration $\left(50 ; 100 ; 150\right.$ and 250 g.L $\left.\mathrm{L}^{-1}\right)$ and found maximum levan formation with $150 \mathrm{~g} . \mathrm{L}^{-1}$ of substrate. Ananthalakshmy and Gunasekaran (1999, 1999a) produced levan with mutant strains of Z. mobilis (ZML1 and ZML2) obtained through the treatment with NTG (N-methyl N'-nitro Nnitroso guanidine), which produced maximum levan concentration of 21.6 and 20.0 g.L. respectively in $24 \mathrm{~h}$ of fermentation at $30^{\circ} \mathrm{C}$ with $150 \mathrm{~g} . \mathrm{L}^{-1}$ of sucrose.

In the present experiment, levan synthesis was higher than the one from Ananthalakshmy and Gunasekaran (1999) when using the same sucrose concentration. This difference was probably due to the fermentation conditions used in this study where fermentation time was longer (72 h). However, in another study, Yoshida et al. (1990) isolated, a strain of Z. mobilis (IN-17-10) from palm juice in southern Asia that produced large quantities of levan (79.5 g. $\mathrm{L}^{-1}$ ) in medium containing 150 g. $\mathrm{L}^{-1}$ of sucrose, which was higher compared to the present study.

According to the results from the study of the effect of different carbon sources tested in the three media (Table 2), it was seen that maximum quantity of levan formed was the same as the maximum amount of consumed substrate. In medium 3 (200 g. $\mathrm{L}^{-1}$ of sucrose) the biopolymer production reached 42.7 g. $\mathrm{L}^{-1}$ and TRS was 15.3 g.L $\mathrm{L}^{-1}$ for a total intake of 184.7 g.. $\mathrm{L}^{-1}$ of substrate consumed (Sc) (Table 2).

Wendt (2001) during a study on levan production by $Z$. mobilis observed that as fermentation proceeded, $\mathrm{pH}$ decreased to a value between 3.8 to 4.5 , due to acid formation; however, the microorganism tolerated low $\mathrm{pH}$ values. Similar 
results for $\mathrm{pH}$ variation were observed in the experiments 1 and 2 and it was also seen that the lowest $\mathrm{pH}$ values were found in the highest sucrose concentration tested and that, consequently, favored higher yields of the biopolymer.

Based on results from experiments 1 and 2, it could be said that the sucrose used as carbon source became the main factor with a positive influence on reaching high yields of the biopolymer. The culture better adapted to medium 3. This was directly related to the different compositions of the media, since growth and levan formation were affected not only by the carbon source but also by the presence of some chemical compounds in the fermentation medium (Belaich and Senez, 1965, Bechers et al., 2002).

Belaich and Senez (1965) demonstrated that many organic compounds from peptone or yeast extract were not used as energy sources for the growth, but as constructive blocks for levan biosynthesis. In the present experiment, the effect of $5 \mathrm{~g} \cdot \mathrm{L}^{-1}$ of yeast extract added to medium 3 positively influenced levan production, and this might have been one of the main factors for reaching better yields of the biopolymer. Similar results were observed by Wendt (2001) during a study with a mutant strain of $Z$. mobilis, which showed that this microorganism produced up to 30 g. $\mathrm{L}^{-1}$ of levan and that the yeast extract concentration influenced its synthesis. Moreover, the author reported that levan production was influenced not only by the relation between carbon/nitrogen, but also between organic/inorganic nitrogen.

The presence of higher ammonium sulphate concentrations in media 1 (3.3 g.. $\left.\mathrm{L}^{-1}\right)$ and 2 (2.0 g. $\left.\mathrm{L}^{-1}\right)$, when compared to medium $3\left(1.0\right.$ g.. $\left.{ }^{-1}\right)$ might have inhibited the biopolymer synthesis, since, in spite of the studies confirming the need of nitrogen in the fermentation medium, it should be in small amounts, avoiding its negative influence on levan production. Table 2 showed that the ash content for the crude polysaccharide varied according to the different media compositions tested. The samples of levan produced in medium 3 exhibited low ash content when compared to the samples from media 2 and 3, in which the high salt concentrations might have interfered in the production. Garcia-Cruz (1997) studied the effect of the addition of different nitrogen sources for levan production and noted that there was no stimulation on the cellular growth pattern and that ammonium sulphate up to $50 \mathrm{mM}$ promoted a slight increase in the polysaccharide production.

Many studies have reported that cellular growth rate of $Z$. mobilis could be influenced by the concentrations of potassium, magnesium, calcium, sodium and chloride ions used. It was seen that the high potassium concentration in medium 2 provided higher bacterial growth rates when compared to the other media. The influence of ions was also noted by Jerez (1993) when studying the effect of the variation of potassium concentration and the study showed that growth rate and the amount of levan formed were proportional to the increase of potassium concentration up to 10 g.L. ${ }^{-1}$. In another study, Vigants et al. (1998) found that the effect of mineral salts such as $\mathrm{KCl}$ and $\mathrm{NaCl}$ not only enhanced levan production, but also exhibited a direct action on the enzyme levansucrase, responsible for the production of this product. Many enzymes of the Entner Doudoroff pathway require cofactors such as magnesium, calcium, potassium for levan production. Hoppner and Doelle (1983) reported that calcium and magnesium activated the pyruvate decarboxylase in Z. mobilis, whereas Bekers et al. $(1999,2001)$ observed that potassium activated the pyruvate quinase.

The levan production by the Z. mobilis was studied by Oliveira et al. (2007) varying the carbon source (commercial sucrose, molasses and sugar cane syrups) and the fermentation medium constituents. Results showed a decrease in levan production in the molasses medium $\left(2.53 \mathrm{~g} . \mathrm{L}^{-1}\right)$ when compared to the commercial sucrose (21.68 g.. $\left.\mathrm{L}^{-1}\right)$ and syrup (15.45 g. $\mathrm{L}^{-1}$ ) media. Yeast extract and $\mathrm{KH}_{2} \mathrm{PO}_{4}$ were significant in the commercial sucrose medium for levan production and in the syrup medium the yeast extract and $\mathrm{MgSO}_{4}$ were significant. Although sugar cane syrup produced about $28.72 \%$ less levan compared to the commercial sucrose, biomass production in the syrup was 2.76 times higher than in the commercial sucrose $\left(0.85\right.$ and 2.36 g.L. $\left.\mathrm{L}^{-1}\right)$ that could justify joint levan and Z. mobilis ATCC 31821 biomass production.

Aeration is also considered a factor that influences levan production. According to Vinhas (1999), during the biopolymer production by Z. mobilis it was not advantageous to promote the agitation, since it led to aeration which consequently damaged the cell and levan production. However, in the present study, agitation did not cause a 
decrease in levan production, which was also found by Han and Clarke (1990), which reported that the polysaccharide production increased when the culture was slightly agitated during fermentation.

\section{Effect of variation of incubation temperature and initial pH}

The results as shown in Table 3 showed that $Z$. mobilis appeared to be osmotolerant and thermotolerant. The growth was proportional to $\mathrm{pH}$ and temperature increase, exhibiting biomass up to 6.7 g. $\mathrm{L}^{-1}$ in fermentation carried out at $35^{\circ} \mathrm{C}$ and $\mathrm{pH}$ 8.0. Lyness and Doelle (1983) and Doelle et al. (1989) reported that high fermentation temperatures $\left(30\right.$ to $42^{\circ} \mathrm{C}$ ) and high initial $\mathrm{pH}$ values (above 5.0) inhibited the production of levansucrase, responsible for levan formation by Z. mobilis. In another study, Jerez (1983) showed that the kinetic parameters were affected by temperature and $\mathrm{pH}$ control, since when using $37^{\circ} \mathrm{C}$, with and without $\mathrm{pH}$ control, specific growth rate was higher and the amount of levan produced was lower when compared to $30^{\circ} \mathrm{C}$. By the analysis of the temperatures tested, it could be seen that at $30^{\circ} \mathrm{C}$, for initial $\mathrm{pH}$ of 6 and 7 , levan yield was similar. At these initial $\mathrm{pH}$ values, average yield of the biopolymer remained around $42.8 \%$, whereas as at initial $\mathrm{pH}$ of 8.0 , the synthesis reduced to $34.4 \%$. At $30^{\circ} \mathrm{C}$, the cellular mass of Z. mobilis was approximately 4.5 g. $\mathrm{L}^{-1}$. However, when the temperature was reduced from 30 to $25^{\circ} \mathrm{C}$, the cellular mass decreased approximately to 4.2 g.. $\mathrm{L}^{-1}$ (Table 3 ).

Table 3 - Levan production by Z. mobilis CCT 4494 in medium 3 containing 200 g.L $\mathrm{L}^{-1}$ of sucrose at different temperatures and $\mathrm{pH}$ values at $200 \mathrm{rpm}$ for $72 \mathrm{~h}$.

\begin{tabular}{|c|c|c|c|c|}
\hline & & & $\mathrm{pH}$ values & \\
\hline & Temperature & 6.0 & 7.0 & 8.0 \\
\hline & final $\mathrm{pH}$ & $4.4( \pm 0.2)$ & $4.6( \pm 0.0)$ & $4.9( \pm 0.1)$ \\
\hline & CM $\left(\right.$ g. $\left.L^{-1}\right)$ & $3.2( \pm 0.2)$ & $4.4( \pm 0.2)$ & $4.9( \pm 0.1)$ \\
\hline $25^{\circ} \mathrm{C}$ & Levan (g.L $\left.\mathrm{L}^{-1}\right)$ & $54.4( \pm 0.3)$ & $83.5( \pm 0.1)$ & $55.7( \pm 0.1)$ \\
\hline & Levan $(\%)$ & $27.2( \pm 0.3)$ & $41.7( \pm 0.1)$ & $27.8( \pm 0.1)$ \\
\hline & TRS (g.L $\left.\mathrm{L}^{-1}\right)$ & $66.7( \pm 0.1)$ & $7.2( \pm 0.4)$ & $61.6( \pm 0.1)$ \\
\hline & $\operatorname{Ash}(\%)$ & $0.6( \pm 0.0)$ & $0.7( \pm 0.1)$ & $0.9( \pm 0.1)$ \\
\hline & final $\mathrm{pH}$ & $4.4( \pm 0.1)$ & $4.4( \pm 0.0)$ & $4.6( \pm 0.1)$ \\
\hline & CM (g.L $\left.{ }^{-1}\right)$ & $4.3( \pm 0.0)$ & $4.6( \pm 0.2)$ & $4.9( \pm 0.1)$ \\
\hline $30^{\circ} \mathrm{C}$ & $\operatorname{Levan}\left(\mathrm{g} \cdot \mathrm{L}^{-1}\right)$ & $85.5( \pm 0.0)$ & $86.1( \pm 0.2)$ & $68.8( \pm 0.0)$ \\
\hline & Levan (\%) & $42.7( \pm 0.0)$ & $43.0( \pm 0.2)$ & $34.4( \pm 0.0)$ \\
\hline & TRS $\left(\right.$ g. $\left.\mathrm{L}^{-1}\right)$ & $18.0( \pm 0.2)$ & $9.5( \pm 0.3)$ & $18.6( \pm 0.3)$ \\
\hline & Ash (\%) & $0.5( \pm 0.0)$ & $0.7( \pm 0.1)$ & $0.8( \pm 0.2)$ \\
\hline & final $\mathrm{pH}$ & $4.2( \pm 0.0)$ & $4.2( \pm 0.0)$ & $4.3( \pm 0.0)$ \\
\hline & $\mathrm{CM}\left(\mathrm{g} . \mathrm{L}^{-1}\right)$ & $5.2( \pm 0.0)$ & $6.3( \pm 0.0)$ & $6.7( \pm 0.0)$ \\
\hline $35^{\circ} \mathrm{C}$ & Levan $\left(\right.$ g. $\left.\mathrm{L}^{-1}\right)$ & $69.9( \pm 0.0)$ & $79.5( \pm 0.0)$ & $4.7( \pm 0.0)$ \\
\hline & Levan $(\%)$ & $34.9( \pm 0.0)$ & $39.7( \pm 0.0)$ & $37.3( \pm 0.0)$ \\
\hline & TRS $\left(\right.$ g. $\left.\mathrm{L}^{-1}\right)$ & $40.9( \pm 0.0)$ & $13.0( \pm 0.0)$ & $20.0( \pm 0.0)$ \\
\hline & Ash $(\%)$ & $0.6( \pm 0.0)$ & $0.8( \pm 0.0)$ & $0.9( \pm 0.0)$ \\
\hline
\end{tabular}

Initial pH: 7.0. CM: cellular mass. TRS: Total Reducing Sugar. ( \pm ): average of three determinations indicating the range upper and lower values obtained for each experiment.

When comparing the yields of levan obtained at $25^{\circ} \mathrm{C}$ with $\mathrm{pH}$ variation, it was seen that the higher value was with initial $\mathrm{pH}$ of 7.0. The biopolymer produced at $25^{\circ} \mathrm{C}(41.7 \%)$ was similar to $30^{\circ} \mathrm{C}$ with initial $\mathrm{pH}$ of 7.0 , with an average yield of $43.0 \%$. For the other $\mathrm{pH}$ values tested at $25^{\circ} \mathrm{C}$, the yields were $27.2 \%(\mathrm{pH} 6.0)$ and $27.8 \%(\mathrm{pH} 8.0)$, which were lower than the one obtained at $30^{\circ} \mathrm{C}$ as $42.7 \%$ (pH 6.0) and 34.4\% (pH 8.0). These results did not agree with Bekers et al. (1999) which reported that optimum temperature for levan production was $25^{\circ} \mathrm{C}$; however, these results were similar to the ones from Park and Baratti (1993), which observed that best yields occurred at $30^{\circ} \mathrm{C}$. Table 3 showed that at $35^{\circ} \mathrm{C}$, the medium with $\mathrm{pH}$ 7.0 produced 79.5 g. $\mathrm{L}^{-1}$ (39.7\%) of levan, which was lower when compared to the ones obtained at 25 and $30^{\circ} \mathrm{C}$. Adjusting the initial pH to 6.0 , the 
yield was $34.9 \% \quad\left(69.9\right.$ g. $\left.L^{-1}\right)$ with 100 g. $L^{-1}$ sucrose, which was better than the one at $25^{\circ} \mathrm{C}$ $(27.2 \%)$ and lower to the one at $30^{\circ} \mathrm{C}(42.7 \%)$. The final $\mathrm{pH}$ of the fermentation medium varied between 4.3 and 4.9. Other researchers also found similar values such as Doelle et al. (1989), who reported that final $\mathrm{pH}$ after three days at $30^{\circ} \mathrm{C}$ in standard medium was between 4.8 and 5.2 and that this decrease represented the formation of acids and the microorganism's tolerance towards low pH values (Wendt, 2001).

The highest levan synthesis occurred at final $\mathrm{pH}$ values from 4.4 to 4.6 , which differed from the results of Park and Baratti (1993), who reported that a $\mathrm{pH}$ between 4.0 and 5.5 during fermentation caused a good cellular growth, but a decrease in levan production. However, the present results were similar to Belghith et al. (1996), who observed that levan formation was more significant in $\mathrm{pH}$ values lower than 6.0 and to the ones of Doelle et al. (1989) of approximately 5.0.

Table 3 showed that sucrose intake for experiments with initial $\mathrm{pH}$ of 6.0 and 8.0 was much lower than that at 7.0. Residual sucrose, expressed as total reducing sugar $\left(\mathrm{g} . \mathrm{L}^{-1}\right)$, was 9.5 g.L $\mathrm{L}^{-1}$ with initial $\mathrm{pH} 7.0$ at optimum temperature for levan production $\left(30^{\circ} \mathrm{C}\right)$. This possibly favored the extracellular sucrase and invertase activities, two of the three enzymes known to be responsible for sucrose hydrolysis (Doelle et al., 1989).

Based on the results, it could be concluded that $\mathrm{pH}$ of the medium and fermentation temperature were the critical factors that most influenced the biopolymer production, and that they must be controlled throughout the whole fermentation process

\section{Effect of the variation of yeast extract}

As noted during the evaluation of the effect of sucrose concentration, levan formation and cellular growth were affected not only by the carbon source but also by the presence of some chemical compounds in the fermentation medium. The quantity of the polysaccharide and cellular mass varied with the different yeast extract concentrations added to medium 3. Figure 2 showed that the growth of Z. mobilis was proportional to the increase in the concentration of yeast extract. However, the same did not occur for levan synthesis. The absence of yeast extract in the production medium promoted a cellular mass of 2.0 g. $\mathrm{L}^{-1}$ and as its concentration increased, cellular mass increased up to 12.6 g. $\mathrm{L}^{-1}$ with the highest concentration tested $\left(10\right.$ g. $\left.\mathrm{L}^{-1}\right)$. For levan synthesis, the best concentration was $5 \mathrm{~g} . \mathrm{L}^{-1}$ of yeast extract with a yield of $42.5 \%$, corresponding to 85 g.L. ${ }^{-1}$ of the biopolymer and as its concentration increased, there was a decrease in yield to $34.2 \%$ (68.5 g.L $\left.\mathrm{L}^{-1}\right)$ with 10 g.L $\mathrm{L}^{-1}$ of yeast extract. Wendt (2001) studied a mutant strain of $Z$. mobilis obtained by treating the natural strain with NTG (N-methyl N'-nitro N-nitroso guanidine). The results showed that this mutant was able to produce up to $30 \mathrm{~g} . \mathrm{L}^{-1}$ of levan and that yeast extract concentration influenced its synthesis.

Figure 2 shows the effect of the addition of yeast extract regarding final $\mathrm{pH}$ value of fermentation medium. The addition of yeast extract kept final $\mathrm{pH}$ value around 4.2 during the $72 \mathrm{~h}$ of incubation. The analysis of TRS showed that the culture consumed small amounts of substrate in the lowest yeast extract concentration $\left(1.0\right.$ - 4.0 initial, g. $\left.\mathrm{L}^{-1}\right)$, which could have negatively interfered in levan synthesis.

The high substrate intake could be directly related to the increase of cellular mass, since the culture's adaptation to the medium containing high concentrations of yeast extract $\left(5-10\right.$ g.. $\left.{ }^{-1}\right)$ favored its growth, as well as levan synthesis. These results supported the need to add yeast extract to the culture medium, but in small amounts to avoid its negative influence on levan synthesis as seen in Figure 2. These values are similar to the ones of Cromie and Doelle (1980), who reported that high yeast extract concentrations increased the cellular mass production, but not necessarily levan synthesis. However, the values are different from Ju et al. (1983), who found 10 g. $\mathrm{L}^{-1}$ of yeast extract to be the optimum concentration for the biopolymer production. 

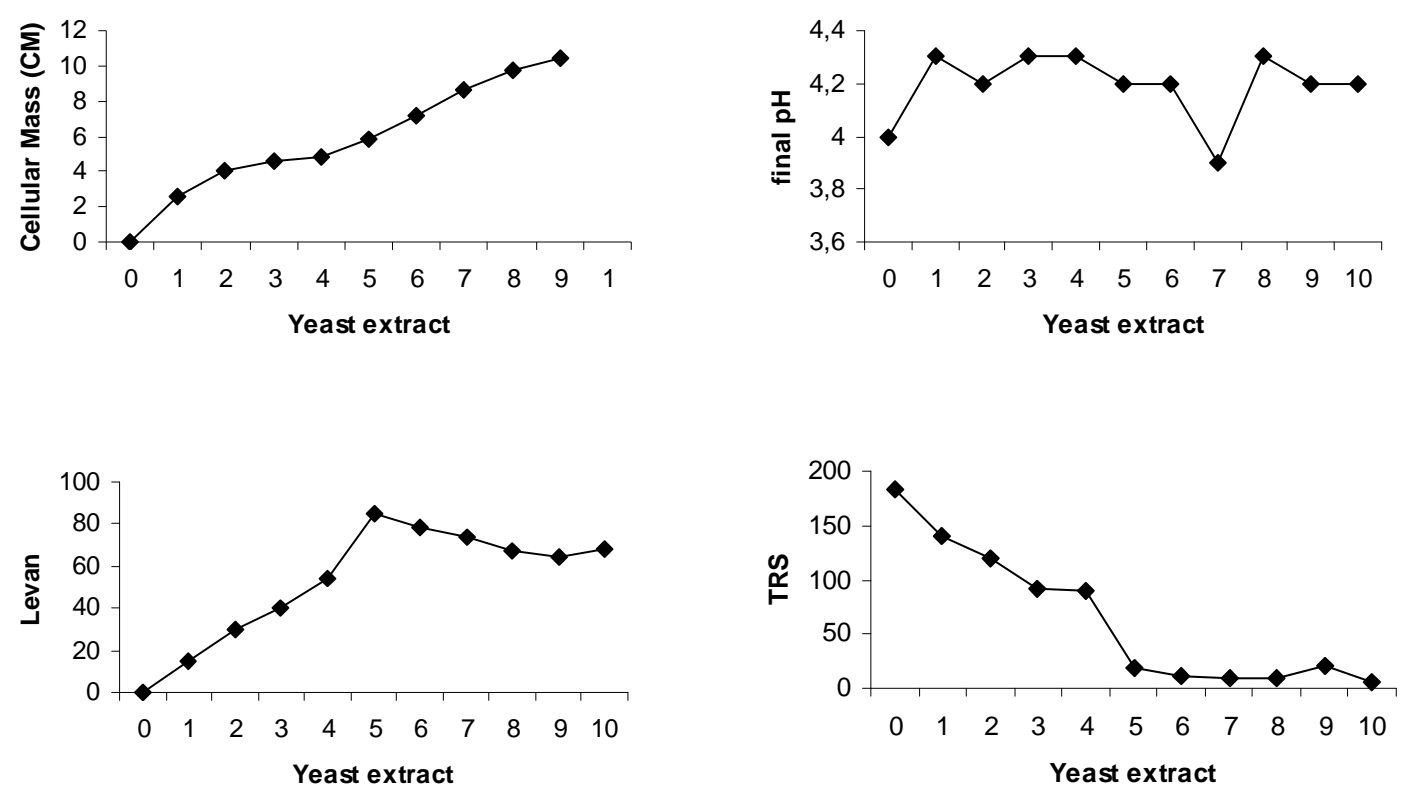

Figure 2 - Effect of the addition of different yeast extract concentrations on cellular mass formation $\left(\mathrm{g} . \mathrm{L}^{-1}\right)$, levan formation $(\%)$, final $\mathrm{pH}$ and $\mathrm{TRS}\left(\mathrm{g} . \mathrm{L}^{-1}\right)$ measurements regarding yeast extract $\left(\mathrm{g} . \mathrm{L}^{-1}\right)$ concentration, during fermentation with $Z$. mobilis CCT 4494 in medium 3, containing 200.0 g. $\mathrm{L}^{-1}$ of sucrose at $30^{\circ} \mathrm{C}$ and $200 \mathrm{rpm}$ for $72 \mathrm{~h}$.

\section{CONCLUSIONS}

Of all the media tested for levan production, medium 3 was the one that most influenced the yields of the biopolymer. The results showed that medium containing $20 \%$ sucrose gave a $42.3 \%$ yield of the biopolymer, equivalent to 85.4 g. $\mathrm{L}^{-1}$, while at concentrations of $10 \%$ and $15 \%$, yields were lower, $26.1 \%$ (26.1 g.L $\left.{ }^{-1}\right)$ and $28.3 \%$ (42.7 g. $\left.\mathrm{L}^{-1}\right)$, respectively. Z. mobilis CCT 4494 exhibited growth proportional to the increase of yeast extract concentration added to medium 3 , where 5.0 g. $\mathrm{L}^{-1}$ was the ideal concentration for levan synthesis. Fermentation carried out at initial $\mathrm{pH}$ range of 6.0 and 7.0 resulted in good amounts of levan that could be precipitated at the end of the process and the ones carried out at $30^{\circ} \mathrm{C}$ showed better results when compared to 25 and $35^{\circ} \mathrm{C}$.

\section{ACKNOWLEDGEMENTS}

The authors are grateful to FAPESP-Brazil for funds to development this work.

\section{REFERENCES}

Amorin, H. V; Zago, E. A. and Oliveira, A. J. (1982), Novos métodos analíticos para controle de fermentação alcoólica. In Soc. Bras. Microbiol. 58p.

Ananthalakshmy, V. K. and Gunasekaran, P. (1999), Isolation and chacterization of mutants from levanproducing Zymomonas mobilis. J. Bioscien. Bioeng. 87, 214-217.

Ananthalakshmy, V. K. and Gunasekaran, P. (1999a), Optimization of levan producing by Zymomonas mobilis. Braz. Arch. Biol. Technol. 42, 291-297.

Bekers, M.; Linde, R.; Danillevich, A.; Kaminska, E.; Upite, D.; Vigants A.; Scherbaka, R. (1999), Sugar beet diffusion and syrup as media for ethanol and levan production by Zymomonas mobilis. Food Biotechnol. 13, 107-119.

Bekers, M.; Laukevics, J.; Karsakecich, A.; Ventina, E.; Kaminska, U. D.; Vina, I.; Linde, R.; Scherbaka, R. (2001), Levan-ethanol biosynthesis using Zymomonas mobilis cells immobilized by attachmente and entrapment. Process Biochem. 36, 979-986.

Bekers, M.; Grube, M; Vulfa, L.; Upite, D.; Kaminska, E.; Scherbaka, R.; Vigants, A.; Danilevich, A. (2002), Biofactors and stimulator of levan synthesis for $Z$. mobilis, Food Technol. Biotechnol. 40, 305-310. 
Belaich, J. P. and Senez, J. C. (1965), Influence of aeration and of penthothenate on growth of Zymomonas mobilis. J. Bacteriol. 89, 1195-1200.

Belghith, H.; Song, K.; Kim, C.; Rhee, S. (1996), Optimal conditions for levan formation by an over expressed recombinant levansucrase. Biotechnol. Lett. 18, 467-472.

Borsari, R. R. J.; Celliogi, M. A. P. C.; Buzato, J. B.; Silva, R. S. S. F. (2006), Influence of carbon source and the fermentation process on levan production by Zymomonas mobilis analyzed by the surface response method. Cin. Tecnol. Alim. 26, 604-609.

Cote, GL and Ahlgren, JA (1993), Metabolism in microorganisms: part I: levan and levansucrase. In: Susuki, N.; Chatterton, N. J. Science and Technology of Fructans, Boca Raton: CRS Press, pp. 142-168.

Cromie, S. and Doelle, H. W. (1980), Relationship between maintenance energy requirements, mineral salts and efficincy of glucose to ethanol conversion by Zymomonas mobilis. Biotecnol. Lett. 2, 357362.DOELLE,

Dadds, M. J. and Martin, P. A. (1973), The genus Zymomonas a review. J. Inst. Brewing. 79, 386-391.

Dawes, E.; Ribbons, D. W. And Rees, D. A. (1966), Sucrose utilization by Zymomonas mobilis: formation of a levan. Biochem. J. 98, 804-812.

Doelle, M.; Millichip, R. and Doelle, H. W. (1989), Production of ethanol from corn using inoculum cacading of Zymomonas mobilis. Process Biochem. 15, 137-140.

Ernandes, F. M. P. G.; Garcia-Cruz, C. H. (2005), Levana Bacteriana: aspectos tecnológicos, características e produção. Semina: Cien. Agrar. 26, 71-82.

Ernandes, F. M. P. G. and Garcia-Cruz, C. H. (2009), Análise dos parâmetros cinéticos para produção de levana por Zymomonas mobilis utilizando fermentação submersa. Acta Scient. Technol. 31, 3541.

Ernandes, F. M. P. G.; Garcia-Cruz, C. H. (2009), Zymomonas mobilis; um microrganismo promissor para a fermentação alcoólica. Semina: Cien. Agrar. 30, 361-380.

Euzenat, O.; Guibert, A. and Combes, D. (1997), Production of fructo-oligosaccharides by levansucrase from Bacillus subtilis C4. Process Biochem. 32, 237-243.

Faria, L. H. G. B. (2002), Caracterização taxonômica e produção de polissacarídeos utilizando bactérias isoladas de amostras de solo. Dissertação de Mestrado, Universidade Estadual Paulista, São José do Rio Preto, Brasil.

Garcia-Cruz, C. H. (1997), Produção de polissacarídeos bacterianos. Thesis de Livre Docente, Universidade Estadual Paulista, São José do Rio Preto, Brasil.
Han, Y. W.; Clarke, M. A. (1990), Production and characterization of microbial levan. J. Agric. Food Chem. 38, 393-396.

Hoppner, T. C. and Doelle, H. W. (1983), Purification and kinetics characteristics of pyruvate decarboxile and ethanol dehydrogenase from Zymomonas mobilis inrelation to ethanol production. Appl. Microbiol. Biotechnol. 17, 152-157.

Instituto Adolfo Lutz. (1985), Normas analíticas do Instituto Adolfo Lutz. In- Métodos químicos e físicos para análise de alimentos, ed. Instituto Adolfo Lutz, Campinas, pp. 27.

Jerez, M. C. D. (1993), Estudo comparativo de diferentes métodos e condições de fermentação de melaço de cana-de-açúcar por Zymomonas mobilis. $\mathrm{PhD}$ Thesis, Universidade Estadual de Campinas, Campinas, Brasil.

Lyness, E. W. and Doelle, H. W. (1983), Levansucrase from Zymomonas mobilis. Biotechnol. Lett. 5, 345350 .

Mello, I. R.; Pimentel, M. F.; Lopes, C. E.; Calazans G. M. T. (2007), Application of fractional factorial design to levan production by Zymomonas mobilis. Braz. J. Microbiol. 38, 45-51.

Miller, G. L. (1959), Use of DNS acid reagent for the determination of reducing sugars. Anal. Chem. 31, 426-428.

Nelson, N. (1944). A photometric adaptation of Somogy method for determination of glucose. Biochem. 153, 375-380.

Ribbons, D. W.; Dawes, E. A. and Rees, D. A. (1962), Levan formation by Zymomonas mobilis (Pseudomonas lindneri). Biochem. J. 88, 45.

Oliveira, M. R.; Silva, R. S. S. F.; Buzato, J. B.; Celligoi, M. A. P. C. (2007), Study of levan production by Zymomonas mobilis using regional low-cost carbohydrate sources. Biochem. Eng. J. 37, 177-183.

Pace, G. W. and Righelato, R. C. (1980), Production of extracellular microbial polysaccharides. $A d v$. Biochem. Eng. 15, 41-70.

Park, S. C. and Baratti, J. (1993), Effects of potassium chloride on ethanol production by an osmotolerant mutant of Zymomonas mobilis. Appl. Microbiol. Biotechnol. 38, 542-549.

Rodriguez, E. and Callieri, D. A. S. (1986), High yield conversion of sucrose into ethanol by a flocculent Zymomonas sp. isolated from sugarcane juice. Biotechnol. Lett. 8, 745-748.

Sangiliyandi, G.; Kannan, T. R.; Raj, C. R. and Gunasekaran, P. (1999), Separation of levan formation and sucrose hydrolysis catalysed by levansucrase of Zymomonas mobilis using in-vitro mutagenesis. Braz. Arch. Biol. Technol. 42, 375-379. 
Somogyi, M. (1952), Notes on sugar determination. $J$. Biol. Chem. 195, 19.

Sutherland, I. W. (2001), Microbial polysaccharides from Gram-negative bacteria. Int. Dairy J. 11, 663674.

Viikari, L. and Gisler, R. (1986), by-products in the fermentation of sucrose by different Zymomonas strains. Appl. Microbiol. Biotechnol. 23, 240-244.

Vigants, A.; Kruce, R.; Bekers, M.; Zikmanis, P. (1998), response of Zymomonas mobilis levansucrase activity to sodium chloride addition. Biotechnol. Lett. 20, 1017-1019.
Vinhas, G. M. (1999), Estudo da produção e do fracionamento de levanas produzidas por Zymomonas mobilis. Dissertação de Mestrado, Universidade Federal de Pernambuco, Recife, Brasil.

Wendt, R. (2001), Estudos da produção de levana através de Zymomonas mobilis. Dissertação de Mestrado, Universidade Estadual de Campinas, Campinas, Brasil.

Received: September 24, 2009; Revised: April 28, 2010; Accepted: February 28, 2011 